\title{
Behaviour Inquiry of Floor Vibration on Composite Structures
}

\author{
S. Karunanidhi, G. Gajalakshmi, Y M S D Sastry
}

\begin{abstract}
In contemporary times, building construction requires light weight with slender structures rather than using conventional materials like concrete. Now a day's Structural Engineers concentrate much more on such slender structures with longer span. The impact of vibration due to human rhythmic activities like aerobics, jumping and dancing on these slender structures is a notable phenomenon. As per the various researchers contemplate, the floor vibrations annoyance not only affect the structure and also its impact over the occupants of the buildings in health affecting aspects. The aim of this paper is to analyse the vibration behavior of composite steel floor structuresunder gymnastic activities like jumping as human rhythmic activities by FEM analysis. The Finite Element Method analysis is done by using ANSYS software. From the Transient analysis of Finite Element method, the peak acceleration values are found out. These peak acceleration values are compared with the recommended values of IS 800-2007 and ISO 2631 - part II. The annoyance of such acceleration values under human rhythmic activities may induce vibration in terms of resonance; the natural frequency of the structural floor may coincide with any of the frequency of such activities. When resonance occurs, even fatigue failure of structures may happen. Hence it is essential for the structural Engineer to undergo the vibration analysis of composite floor structures during design stage itself.In order to check over such problems, in this paper as a novelty; a mathematical model is developed using SPSS software.This mathematical model is for peak acceleration values which helps the structural designer to analyse vibration problems under human rhythmic activities.
\end{abstract}

Keywords : Vibration; Rhythmic activity; Composite structures; Acceleration; ANSYS; SPSS software

\section{INTRODUCTION}

Of late, the modern architecture and construction trends are motivating the structural engineer to search for challenging solutions. The recent evolution in building construction could be attributed to fast erection assembly with optimum weight duly supporting large spans with lesser columns facilitating greater space flexibility.

Owing to the impacts like human rhythmic activities, the structures floor systems are vulnerable to excess vibrations.

Revised Manuscript Received on April 25, 2020.

* Correspondence Author

Mr. S. Karunanidhi*, Civil Engineering, Wollega University, Ethiopia, Email: karunabalasingam@gmail.com

Dr.G.Gajalakshmi, Civil Engineering,, Wollega University, Ethiopia.

Mr. YMSD Sastry, CE, BVC Engineering College, JNTUK, Odalarevu, India. Email: dattasastry@gmail.com

(C) The Authors. Published by Blue Eyes Intelligence Engineering and Sciences Publication (BEIESP). This is an open access article under the CC BY-NC-ND license (http://creativecommons.org/licenses/by-nc-nd/4.0/)
Vibrations due to this activity have created problems in office buildings, foot-bridges, shopping malls and sport stadia ${ }^{7}$. Recently the dynamic behavior of these composite floor systems is being investigated by various authors analytically using Finite Element Method is a modern computational analytical tool which is for structural dynamic analysis. In order to increase slender and lightness of the structural systems, designers continuously progress to safety margins. More and more composite floors, steel floors are constructed as light weight structures with low damping and low frequencies, but perceptive to vibration consequently changing the serviceability and ultimate limit state associated with their design.

Starting from Reiherand meister[12], Bruce Ellingwood ${ }^{3}$ and more number of researchers attempted to find solution for vibration excitation. Allen [1], developed a design procedure by solving problems for different structural properties for different usage. S. Sanden de Silva et al [9] states that steel deck composite floor with increased acceleration cause discomfort to the occupants.

Nor Hayati and Abd Ghafer[11] made a research work on dynamic behaviour of LVL concrete composite floor system and concluded the natural frequency must exceed $8 \mathrm{~Hz}$ to prevent vibration problems.

The collapse of Hyatt Regency Hotel walkway in Kansas City US happened weekend tea dance in 1981(McGrath and Foote 1981) [11] which caused many lives was a typical example for structural failure. As no information and appropriate theories were then available the people were kept in darkness regarding cause of the destruction.

Kromanis $\mathrm{R}$ and Kripakaran $\mathrm{P}[8]$ investigated the application of novel computational techniques for structural performance monitoring of National Physical Laboratory (NPL) footbridge bridges truss and concrete footbridge that enable quantification of temperature-induced response during the strain measurement interpretation process. The Results show that the methodology is capable of accurately predicting thermal response and can therefore help with interpreting measurements from continuous National Physical Laboratory (NPL) footbridge bridges truss and concrete footbridge monitoring.

It could be concluded from the above literature study that the understanding of human interaction to the structure is a complex phenomenon. Some equations and formula are arrived at by all researchers from their input data based on the corresponding human activities. Moreover many factors like the posture of the occupants, dynamic properties of the structure and the mass of the

Published By:

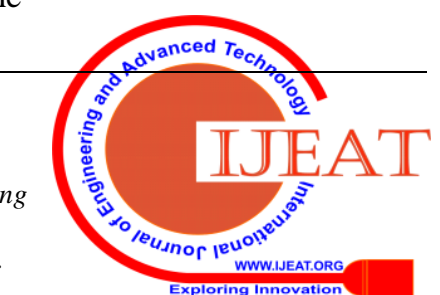


people which induce activities such as jumping; aerobics, walking etc determine the dynamic response.

As the type of activity carried out by a single person might generate perceptible levels of vibration in a number of floors, no straight calculation is in existence for fundamental frequency. As such all the results obtained in various applications are not specific, ambiguous since the data are sparse, incoherent and devoid of continuity.

\section{A. Objective}

The aim of this paper is to analyse the dynamic behavior for composite steel construction like steel floors with concrete topping for different occupancy usage under serviceable condition for human rhythmic activity (Jumping). The various structure models are to be analysed using Finite Element Method -ANSYS2 software. The analytical values obtained were compared with code recommendations.

\section{B. Novelty}

In order to mitigate the setbacks relating to the vibration problem, a novel mathematical model based on software SPSS has been arrived with reference for composite steel structures.

\section{DYNAMIC ANALYSIS OF STRUCTURAL MEMBERS}

\section{A. Loads generated by human activities}

The dynamic loads have considered by Faisca $(2003)^{4}$ who achieved the same through a long series of various experiments executed with human activities as dynamic loads are described as jumps with and without stimulation, aerobics, soccer, rock concert audiences and dancing. based on results achieved through a long series of experimental tests made with individuals carrying out rhythmic and non-rhythmic activities. Human activities such as aerobics, Gymnastics dancing and free jumps can be simulated by the load modelling.

The mathematical representation is very much analogous to the signal force generated through experiments and it is described by the equation(2.1). Some parameters like the activity period $\mathrm{T}$, contact period with the structure Tc, period without contact with the model Ts, impact coefficient Kp, and phase coefficient CD are required for this equation.

$$
\begin{aligned}
& \mathrm{F}(\mathrm{t})=\mathrm{CD}\left\{\mathrm{K}_{\mathrm{p}} \mathrm{P}\left[0.5-0.5 \cos \left(\frac{2 \pi}{\mathrm{T}_{\mathrm{c}}} \mathrm{t}\right)\right]\right\} \text {, for } \mathrm{t} \leq \mathrm{T}_{\mathrm{c}} \\
& \mathrm{F}(\mathrm{t})=0 \text {, for } \mathrm{T}_{\mathrm{c}}<\mathrm{t} \leq \mathrm{T} \\
& \begin{array}{ccc}
\text { Where } \quad \mathrm{F}(\mathrm{t}) & - & \text { Dynamic loading, in }(\mathrm{N}) ; \\
\mathrm{t} & - & \text { Time, in (s); } \\
\mathrm{T} & - & \text { Activity period (s); } \\
\mathrm{T}_{\mathrm{c}} & - & \text { Activity contact period (s); } \\
\mathrm{P} & - & \text { Weight of the individual }(\mathrm{N}) ; \\
\mathrm{K}_{\mathrm{p}} & - & \text { Impact coefficient; } \\
\mathrm{CD} & - & \text { Phase coefficient. }
\end{array}
\end{aligned}
$$

\section{B. Structural Configuration Details}

\section{Structural Floor Details}

- Span of the Composite floor systems are: $16 \mathrm{~m} \mathrm{x}$ 12m,8mx 6m, 4mx 3m,8mx 12m, 6mx 10m, 2mx 1m

- Youngs Modulus for the steel beams : 2.4x 105 Mpa.

- Density of Steel: $7850 \mathrm{~kg} / \mathrm{m}^{3}$.

- Density of Concrete: $2500 \mathrm{~kg} / \mathrm{m}^{3}$

- Yield stress: $300 \mathrm{Mpa}$.

The above composite floor system panels are analysed using FEM are

a) Modal analysis b)Harmonic analysis and c)Transient analysis.

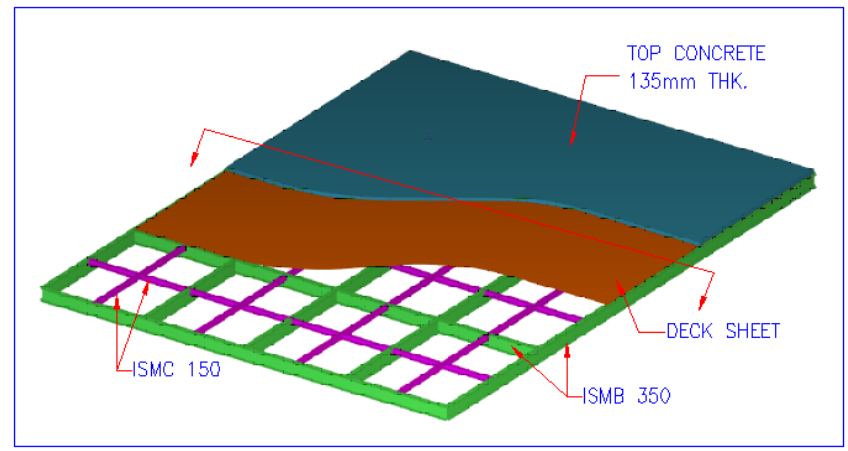

Fig 2.1. Structural model three-dimensional plan view

\section{Finite Element Analysis using Ansys}

For dynamic floor analysis for the proposed computational model, adopted the usual mesh refinement techniques present in finite element method simulations implemented in the ANSYS program (ANSYS, 11). In this model, the floor beams are represented by three-dimensional beam elements (BEAM44), tension, compression, bending and torsion capabilities. The floor slab is represented by shell finite elements (SHELL63 and SHELL 99).

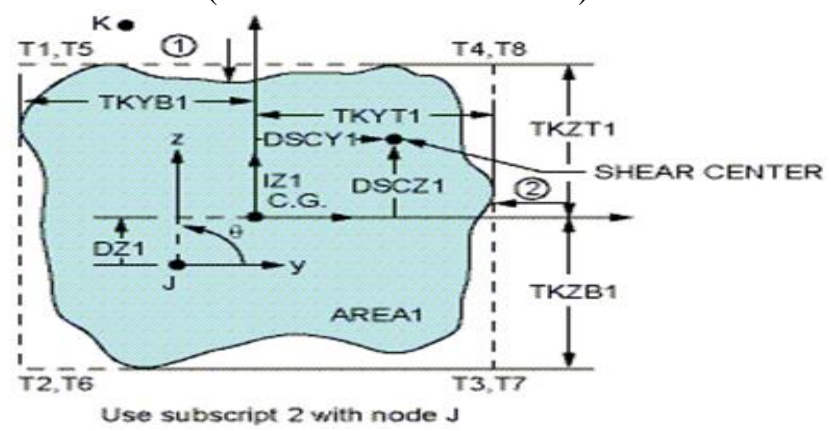

Fig 2.2. 3-D Elastic Tapered Unsymmetric

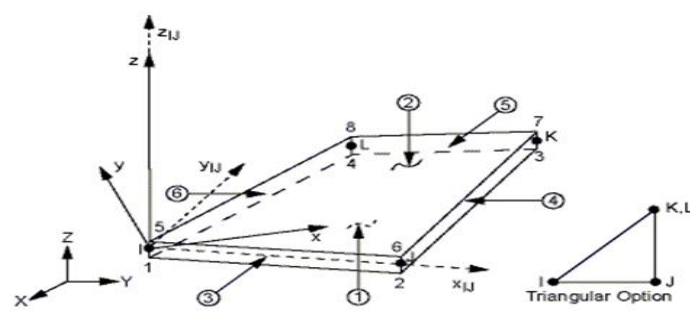

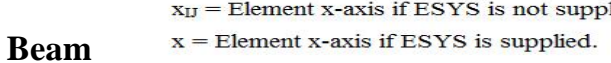

Fig 2.3. Elastic Shell

Model results of ANSYS for $16 \mathrm{mx} 12 \mathrm{~m}$ are- modal shape, natural frequency, harmonic analysis and transient analysis are given below.

\section{Published By:}

Blue Eyes Intelligence Engineering

\& Sciences Publication

DOI: 10.35940/ijeat.D8351.049420

Journal Website: www.ijeat.org

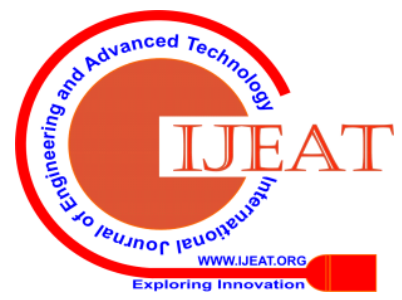




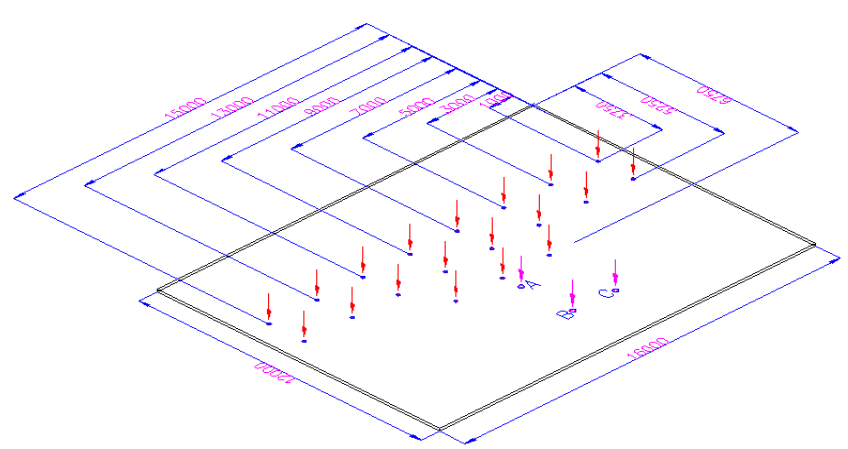

Fig 2.4. Load distribution Scheme associated to eighteen individuals practicing

D. Modal analysis and the mode shapes

Table 2.1. Mode shapes and natural frequencies

\begin{tabular}{|c|l|l|l|r|r|r|}
\hline $\begin{array}{c}\text { Mode } \\
\text { shapes }\end{array}$ & $\mathbf{1}$ & $\mathbf{2}$ & $\mathbf{3}$ & $\mathbf{4}$ & $\mathbf{5}$ & $\mathbf{6}$ \\
\hline $\begin{array}{c}\text { Natural } \\
\text { frequencie } \\
\mathbf{s}(\mathbf{H z})\end{array}$ & 3.48 & $\begin{array}{l}9.48 \\
0\end{array}$ & $\begin{array}{l}12.67 \\
5\end{array}$ & $\begin{array}{r}1 \\
5.836\end{array}$ & $\begin{array}{r}1 \\
6.260\end{array}$ & $\begin{array}{l}22.01 \\
0\end{array}$ \\
\hline
\end{tabular}

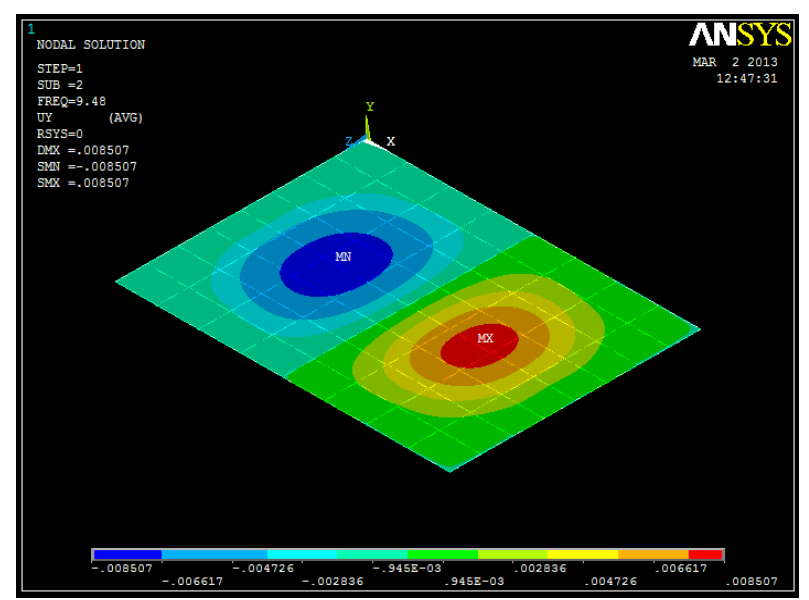

Fig 2.5. Vibration mode associated to the 2nd natural frequency: $F 02=9.480$

E. Harmonic Analysis

- Results for three persons loading

The following graphs shows the dynamic response of FE model composite floor system with three persons loading

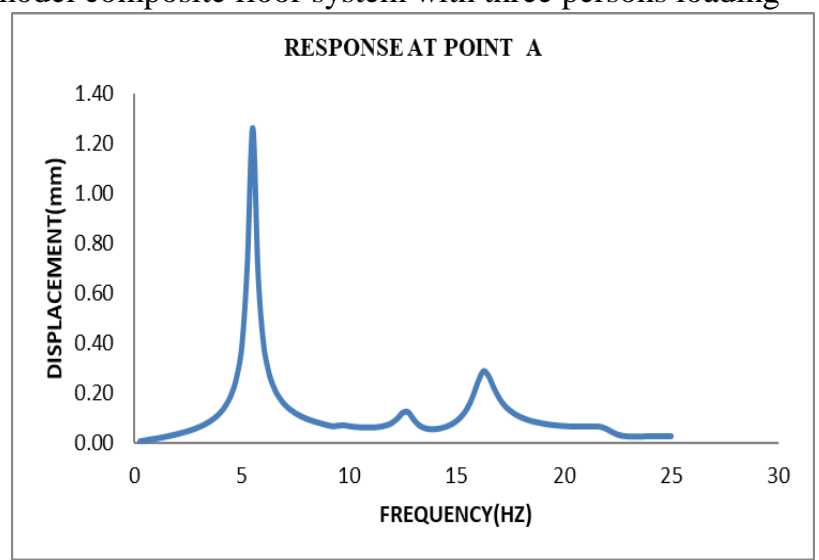

Fig 2.6. Frequency Vs Displacement for Three persons at Measuring Point A

Transient Analysis Results for five persons loading
The following Figure presents the Acceleration versus Time graphs for the analyzed Composite Concrete Floor at measuring point $\mathrm{A}, \mathrm{B}, \mathrm{C}$, when only five persons load is acting on the structural Model(Aerobic).

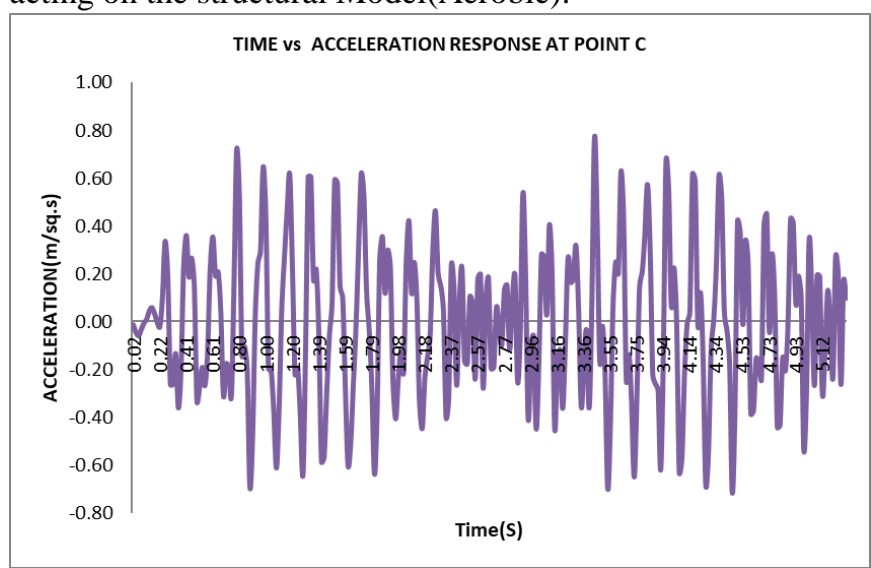

Fig 2. 7. Time Vs Acceleration Response for 5 persons at Measuring Point $\mathrm{C}$

Table 2.2. Comparison of peak acceleration results with Threshold limits

\begin{tabular}{|c|c|c|c|c|c|}
\hline \multirow{2}{*}{$\begin{array}{l}\text { Number } \\
\text { of } \\
\text { Persons }\end{array}$} & \multicolumn{3}{|c|}{$\begin{array}{l}\quad \text { Peak } \\
\text { Acceleration } \\
(\mathbf{m} / \mathbf{s q . s})\end{array}$} & \multirow{2}{*}{$\begin{array}{l}\text { Max peak } \\
\text { acceleration }\end{array}$} & \multirow{2}{*}{$\begin{array}{l}\text { Threshold } \\
\text { limits } \mathbf{a}_{\lim }\end{array}$} \\
\hline & $\begin{array}{r}\text { Poi } \\
\text { nt A }\end{array}$ & $\begin{array}{l}\text { Point } \\
\text { B }\end{array}$ & $\begin{array}{l}\text { Point } \\
\text { C }\end{array}$ & & \\
\hline 1 & 0.27 & 0.247 & 0.24 & 0.27 & \multirow{3}{*}{$\begin{array}{c}0.5 \% \text { g as } \\
\text { per } \\
\text { IS800-2007 } \\
6\end{array}$} \\
\hline 3 & 0.737 & 0.644 & 0.557 & 0.737 & \\
\hline 5 & 0.94 & 0.824 & 0.767 & 0.94 & \\
\hline 7 & 1.41 & 1.17 & 1.16 & 1.41 & \multirow{3}{*}{$\begin{array}{l}\text { 5\% g as per } \\
\text { ISO-2631 } \\
\text { (PART-II) }^{5}\end{array}$} \\
\hline 11 & 2.01 & 1.66 & 1.59 & 2.01 & \\
\hline 19 & 3.54 & 2.95 & 2.69 & 3.54 & \\
\hline
\end{tabular}

Likewise the dynamic analysis for other panels like $10 \mathrm{mx}$ $8 \mathrm{~m}, 8 \mathrm{mx} 6 \mathrm{~m}, 6 \mathrm{mx} 10 \mathrm{~m}, 8 \mathrm{mx} 12 \mathrm{~m}$, $4 \mathrm{mx} 3 \mathrm{~m}, 2 \mathrm{~m} x 1 \mathrm{~m}$ are analysed and their corresponding structural properties and results are given as inputs for generating a regression mathematical model using SPSS software.

\section{RESULTS AND DISCUSSION ON ANALYTICAL RESULTS}

From the results with reference to Table 2., the threshold limit for acceleration as per IS 8002007 for human rhythmic activity is $0.5 \% \mathrm{~g}$. For one person loading condition for jumping activity, the peak acceleration value is $0.27 \mathrm{~m} / \mathrm{sec} 2$. Nearly $81 \%$ value is increased when compared with IS800-20075. Therefore composite steel floor is vulnerable to vibration due to the impact of jumping activity. The floor is not supported to jumping activity from 3 persons loading condition when compared to the threshold limit of $5 \% \mathrm{~g}$ as per ISO 2631(part II)6.

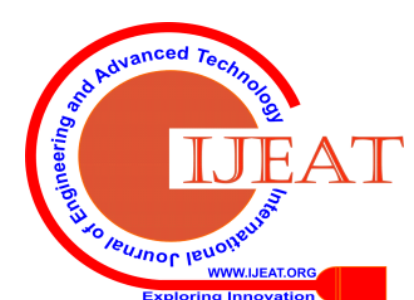




\section{Behaviour Inquiry of Floor Vibration on Composite Structures}

\section{- Mathematical model using SPSS software}

SPSS software is used for data analysis using statistical techniques. There are many statistical packages are available for data analysis Minitab, SAS, STATA. But SPSS is the most widely used software. This software can be used in all domains like finance, healthcare, bio engineering etc. SPSS (Statistical Package for the Social Sciences) is a software package used for statistical analysis. Long produced by SPSS Inc., it was acquired by IBM in 2009. The current versions (2015) are officially named IBM SPSS Statistics. Companion products in the same family are used for survey authoring and deployment (IBM SPSS Data Collection), data mining (IBM SPSS Modeler), text analytics, and collaboration and deployment (batch and automated scoring services). SPSS contains two views. They are two views in the SPSS such as data view and variable view. Data view is used to store data and variable view is used to define variables.

\section{- Multiple regression model development}

Regression analysis is mathematical measure of average relationship between two or more variables in terms of original units of data. Regression is used to create an equation or transfer function from the measurements of the system's inputs or outputs acquired during a passive or active experiment. Multiple regression analysis was conducted using displacement (d) and Acceleration (a) as a dependent variable and area (A), Moment of Inertia (IZ1, IY1). Web thickness (TKyB1) as the independent variables.

\section{Regression Analysis}

For acceleration

SPSS 16 was used to analyze the response of this study. Person correlation was use to analyze correlation among the 7 variables. All the variables were significantly correlated with one another at 0.001

$$
\mathrm{d}=\mathrm{f}(\mathrm{A}, \mathrm{IZ} \neg \neg \neg \neg \neg 1, \mathrm{IY} 1, \mathrm{KZB} 1, \mathrm{TKYB} 1)
$$

KZB1, TKYB1 are not significant in the explaining the variation in acceleration we developed the reduced regression that excluded the variables.

The reduced model has the following form:

$$
\mathrm{d}=\mathrm{f}(\mathrm{A}, \mathrm{IZ1} \text {, IY1) }
$$

Predictors: (Constant), TKYB1, IZ1, A

\begin{tabular}{|c|c|c|c|c|c|c|c|c|c|}
\hline & & A & Z1 & IY1 & IX1 & TKZB1 & $\begin{array}{c}\text { TKY } \\
\text { B1 }\end{array}$ & $\begin{array}{c}\text { displacem } \\
\text { ent }\end{array}$ & acc \\
\hline \multirow[t]{3}{*}{ A } & $\begin{array}{l}\text { Pearson } \\
\text { Correlatio } \\
\mathrm{n}\end{array}$ & 1 & $946^{*}$ & .990 & .949 & $.246^{*}$ & $.944^{* *}$ & $.541^{* *}$ & .611 \\
\hline & $\begin{array}{l}\text { Sig. } \\
\text { (2-tailed) }\end{array}$ & & 000 & .000 & .000 & .050 & .000 & .000 & .000 \\
\hline & $\mathrm{N}$ & $\begin{array}{l}6 \\
4\end{array}$ & 4 & 64 & 64 & 64 & 64 & 64 & 64 \\
\hline \multirow[t]{3}{*}{ IZ1 } & \begin{tabular}{|l} 
Pearson \\
Correlatio \\
n
\end{tabular} & $46^{.9 *}$ & & .969 & $\begin{array}{r}1.00 \\
0^{* * *}\end{array}$ & $.262^{*}$ & $.891^{* *}$ & $.593^{* *}$ & .548 \\
\hline & $\begin{array}{l}\text { Sig. } \\
\text { (2-tailed) }\end{array}$ & $\begin{array}{r}.0 \\
00\end{array}$ & & .000 & .000 & .036 & .000 & .000 & .000 \\
\hline & $\mathrm{N}$ & $\begin{array}{l}6 \\
4\end{array}$ & 4 & 64 & 64 & 64 & 64 & 64 & 64 \\
\hline
\end{tabular}

Table 3.1. Correlations

\begin{tabular}{|c|c|c|c|c|c|c|c|c|c|}
\hline \multirow[t]{3}{*}{$\begin{array}{l}\text { IY } \\
1\end{array}$} & $\begin{array}{l}\text { Pearson } \\
\text { Correlatio } \\
\mathrm{n}\end{array}$ & $\begin{array}{r}.9 \\
90^{* *}\end{array}$ & $969^{*}$ & 1 & $\mid \begin{array}{r}.971 \\
* *\end{array}$ & $.253^{*}$ & $.940^{* *}$ & $.564^{* *}$ & .619 \\
\hline & $\begin{array}{l}\text { Sig. } \\
\text { (2-tailed) }\end{array}$ & $\begin{array}{r}.0 \\
00\end{array}$ & 000 & & .000 & .044 & .000 & .000 & .000 \\
\hline & $\mathrm{N}$ & $\begin{array}{l}6 \\
4\end{array}$ & 4 & 64 & 64 & 64 & 64 & 64 & 64 \\
\hline \multirow[t]{3}{*}{$\begin{array}{l}\mathrm{IX} \\
1\end{array}$} & $\begin{array}{l}\text { Pearson } \\
\text { Correlatio } \\
\mathrm{n}\end{array}$ & $49^{.9}$ & .000 & $.971_{* *}$ & 1 & $.262^{*}$ & $.894^{* *}$ & $.592^{* *}$ & .552 \\
\hline & $\begin{array}{l}\text { Sig. } \\
\text { (2-tailed) }\end{array}$ & $\begin{array}{r}.0 \\
00\end{array}$ & 000 & .000 & & .036 & .000 & .000 & .000 \\
\hline & $\mathrm{N}$ & $\begin{array}{l}6 \\
4\end{array}$ & 4 & 64 & 64 & 64 & 64 & 64 & 64 \\
\hline \multirow[t]{3}{*}{$\begin{array}{l}\mathrm{TK} \\
\mathrm{ZB} \\
1\end{array}$} & $\begin{array}{l}\text { Pearson } \\
\text { Correlatio } \\
\mathrm{n}\end{array}$ & $\begin{array}{r}.2 \\
46^{*}\end{array}$ & $262^{*}$ & $\begin{array}{r}.253 \\
*\end{array}$ & $\mid 262$ & 1 & $.287^{*}$ & .206 & $.247_{*}$ \\
\hline & $\begin{array}{l}\text { Sig. } \\
\text { (2-tailed) }\end{array}$ & $\begin{array}{r}.0 \\
50\end{array}$ & 036 & .044 & .036 & & .022 & .103 & .049 \\
\hline & $\mathrm{N}$ & $\begin{array}{l}6 \\
4\end{array}$ & 4 & 64 & 64 & 64 & 64 & 64 & 64 \\
\hline \multirow[t]{3}{*}{$\begin{array}{l}\text { TK } \\
\text { YB } \\
1\end{array}$} & $\begin{array}{l}\text { Pearson } \\
\text { Correlatio } \\
\mathrm{n}\end{array}$ & $44^{* *}$ & $891_{*}^{*}$ & .940 & .894 & $.287^{*}$ & 1 & $.590^{* *}$ & $.720_{* *}$ \\
\hline & $\begin{array}{l}\text { Sig. } \\
\text { (2-tailed) }\end{array}$ & $\begin{array}{r}.0 \\
00\end{array}$ & 000 & .000 & .000 & .022 & & .000 & .000 \\
\hline & $\mathrm{N}$ & $\begin{array}{l}6 \\
4\end{array}$ & 4 & 64 & 64 & 64 & 64 & 64 & 64 \\
\hline \multirow{3}{*}{$\begin{array}{l}\text { dis } \\
\text { pla } \\
\text { ce } \\
\text { me } \\
\text { nt }\end{array}$} & $\begin{array}{l}\text { Pearson } \\
\text { Correlatio } \\
\mathrm{n}\end{array}$ & $41^{.5 *}$ & $593_{*}^{*}$ & $\begin{array}{r}.564 \\
* * \\
\end{array}$ & .592 & .206 & $.590^{* * *}$ & 1 & .735 \\
\hline & $\begin{array}{l}\text { Sig. } \\
\text { (2-tailed) }\end{array}$ & $\begin{array}{r}.0 \\
00\end{array}$ & 000 & .000 & .000 & .103 & .000 & & .000 \\
\hline & $\mathrm{N}$ & $\begin{array}{l}6 \\
4\end{array}$ & 4 & 64 & 64 & 64 & 64 & 64 & 64 \\
\hline \multirow[t]{3}{*}{ acc } & $\begin{array}{l}\text { Pearson } \\
\text { Correlatio } \\
\mathrm{n}\end{array}$ & $11^{* 6 *}$ & $548_{*}^{*}$ & .619 & .552 & $.247^{*}$ & $.720^{* *}$ & $.735^{* *}$ & 1 \\
\hline & $\begin{array}{l}\text { Sig. } \\
\text { (2-tailed) }\end{array}$ & $\begin{array}{r}.0 \\
00\end{array}$ & 000 & .000 & .000 & .049 & .000 & .000 & \\
\hline & $\mathrm{N}$ & $\begin{array}{l}6 \\
4\end{array}$ & 4 & 64 & 64 & 64 & 64 & 64 & 64 \\
\hline & is & sig & ifican & $\mathrm{dt}$ & le 0. & 2-tail & led). & & \\
\hline
\end{tabular}

Acceleration - Regression Full model

Acceleration full model

Table 3.2. Model Summary

\begin{tabular}{|c|c|c|c|c|}
\hline Model & $\mathbf{R}$ & R Square & $\begin{array}{c}\text { Adjusted R } \\
\text { Square }\end{array}$ & $\begin{array}{c}\text { Std. Error of the } \\
\text { Estimate }\end{array}$ \\
\hline 1 & $.878^{\mathrm{a}}$ & .771 & .747 & .65743038408 \\
\hline
\end{tabular}

Table 3.3. ANOVA ${ }^{b}$

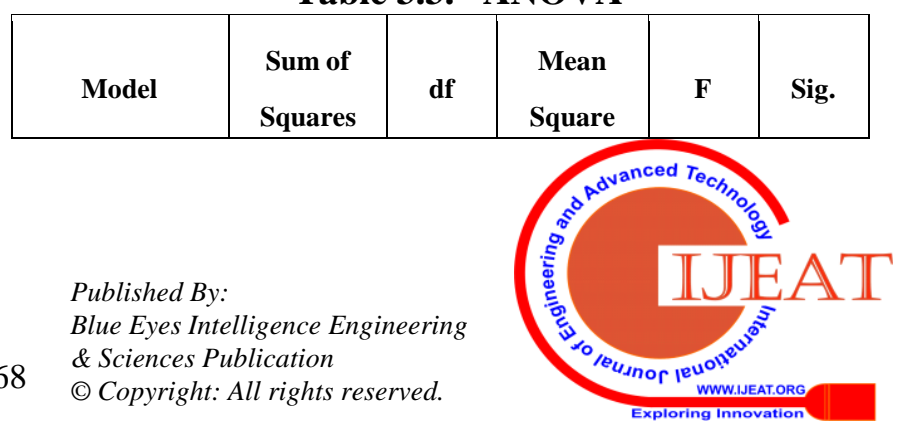




\begin{tabular}{|c|c|c|c|c|c|c|}
\hline \multirow{4}{*}{1} & Regression & 82.920 & 6 & 13.820 & 31.975 & $.000^{\mathrm{a}}$ \\
\cline { 2 - 7 } & Residual & 24.636 & 57 & .432 & & \\
\cline { 2 - 7 } & Total & 107.556 & 63 & & & \\
\hline
\end{tabular}

a. Predictors: (Constant), displacement, TKZB1, A, TKYB1, IZ1, IY1

b. Dependent Variable: acc

Table 3.4 Coefficients ${ }^{\mathrm{a}}$

\begin{tabular}{|c|c|c|c|c|c|}
\hline \multirow{2}{*}{ Model } & \multicolumn{2}{|c|}{$\begin{array}{c}\text { Unstandardized } \\
\text { Coefficients }\end{array}$} & $\begin{array}{c}\text { Standardized } \\
\text { Coefficients }\end{array}$ & \multirow{2}{*}{ t } & \multirow{2}{*}{ Sig. } \\
\cline { 2 - 6 } & B & Std. Error & Beta & & \\
\hline \multirow{2}{*}{ (Constant) } & -1.756 & .804 & & -2.185 & .033 \\
\hline \multirow{2}{*}{1} & -602.190 & 341.613 & -.871 & -1.763 & .083 \\
\hline A & -41399.111 & 9928.032 & -1.206 & -4.170 & .000 \\
\hline IY1 & 1229817.785 & 494641.797 & 1.598 & 2.486 & .016 \\
\hline TKZB1 & .605 & 1.079 & .037 & .561 & .577 \\
\hline TKYB1 & 1490.666 & 398.890 & .776 & 3.737 & .000 \\
\hline displacement & .851 & .127 & .555 & 6.703 & .000 \\
\hline
\end{tabular}

a. Dependent Variable: acc

ACC reduced

Table 3.5. Model Summary

\begin{tabular}{|c|c|c|c|c|}
\hline Model & $\mathbf{R}$ & R Square & $\begin{array}{c}\text { Adjusted R } \\
\text { Square }\end{array}$ & $\begin{array}{c}\text { Std. Error of the } \\
\text { Estimate }\end{array}$ \\
\hline 1 & $.767^{\mathrm{a}}$ & .589 & .561 & .86586205000 \\
\hline
\end{tabular}

a. Predictors: (Constant), TKYB1, IZ1, A, IY1

Table 3.6. ANOVA

\begin{tabular}{|c|r|r|r|r|r|r|}
\hline \multicolumn{2}{|c|}{ Model } & \multicolumn{1}{c|}{$\begin{array}{c}\text { Sum of } \\
\text { Squares }\end{array}$} & \multicolumn{1}{c|}{ df } & \multicolumn{1}{c|}{$\begin{array}{c}\text { Mean } \\
\text { Square }\end{array}$} & \multicolumn{1}{c|}{ F } & \multicolumn{1}{c|}{ Sig. } \\
\hline \multirow{2}{*}{1} & Regression & 63.323 & 4 & 15.831 & 21.116 & $.000^{\mathrm{a}}$ \\
\cline { 2 - 7 } & Residual & 44.233 & 59 & .750 & & \\
\cline { 2 - 7 } & Total & 107.556 & 63 & & & \\
\hline
\end{tabular}

a. Predictors: (Constant), TKYB1, IZ1, A, IY1

b. Dependent Variable: acc

Table 3.7. Coefficients ${ }^{\mathrm{a}}$

\begin{tabular}{|c|c|c|c|c|c|c|}
\hline & \multirow[t]{2}{*}{ Model } & \multicolumn{2}{|c|}{$\begin{array}{c}\text { Unstandardized } \\
\text { Coefficients }\end{array}$} & \multirow{2}{*}{$\begin{array}{c}\text { Standardized } \\
\text { Coefficients } \\
\text { Beta }\end{array}$} & \multirow{2}{*}{$\mathbf{t}$} & \multirow[t]{2}{*}{ Sig. } \\
\hline & & B & Std. Error & & & \\
\hline 1 & Constant) & -2.911 & 1.034 & & -2.814 & .007 \\
\hline & A & -915.125 & 445.620 & -1.324 & -2.054 & .044 \\
\hline
\end{tabular}

\begin{tabular}{|c|c|c|c|c|c|}
\hline IZ1 & -25051.631 & 12646.276 & -.730 & -1.981 & .052 \\
\hline IY1 & 1155100.942 & 650877.390 & 1.500 & 1.775 & .081 \\
\hline TKYB1 & 2321.652 & 494.234 & 1.209 & 4.697 & .000 \\
\hline
\end{tabular}

Regression Full model

Acceleration $=-602.190 \mathrm{~A}-$

$41399.111 I Z 1+1229817.785 I Y 1+$

$0.605 T K Z B 1+1490.666$ TKYB $1+0.851 D-$

1.756

\section{Regression Reduced model}

Acceleration $=-915.125 \mathrm{~A}-25051.631 \mathrm{IZ} 1+$ $1155100.94 I Y 1+2321.65 T K Y B 1-2.911$

Model Validation:

In the above Equation , the significant error is at and TKZB1 as 0.577.Hence the Equation is reduced as shown in Equation , in which significant errors are at 0.01 level. The reduced regression model has explained the variation accounts for $58.9 \%$ which is the best model for validation.

The resulting multiple regression model is From above Equation and, there is a positive relationship between Acceleration with IY1 and TKZB1. But there is a negative relationship between the area and acceleration.

\section{CONCLUSION}

The floor vibration of composite steel structures are analysed using Finite Element method under ANSYS software for human rhythmic activities. The peak acceleration values are obtained from transient analysis and they are compared with IS 800-2007 and ISO 2631.

The resonance formation under deviated acceleration values lead occupancy health problems and also fatigue failure to structures. To mitigate such vibration resonance problems, a mathematical model for acceleration parameter is developed using SPSS software. This mathematical model incorporates the various properties of composite steel structures and helps the structural Engineer to check and control the vibration problems due to human rhythmic activities at the design process itself.

Some of the suggestions to control the vibration problems over engineering structures for human rhythmic activities are summarized below:

- To install a steel girder as a supporting structure underneath the existing floor

- To increase damping, it is recommended to use partition walls and planters with low cost method to increase damping.

- By providing separate ceilings and partitions immediately below the jumping floor by supporting the ceiling on its own framing and by not extending partition to the floor above.

Published By:

Blue Eyes Intelligence Engineering

\& Sciences Publication

(C) Copyright: All rights reserved. 


\section{Behaviour Inquiry of Floor Vibration on Composite Structures}

\section{REFERENCES}

1. Allen, D.E. (1990), "Building Vibrations from Human Activities, Reprinted from American Concrete Institute", Concrete International; Design and Construction, Vol.12, No.6. pp.66-73, (IRC Paper No:1679).

2. ANSYS, Swanson Analysis Systems (2003), Inc.P.O. Box 65, Johnson Road, Houston, P.A.15342-0065, Version11.0. Basic analysis procedures.

3. Bruce Ellingwood, M.and Andrew Tallin, M. (1983), "Structural serviceability:Floor vibrations", Journal of Structural Engineering, ASCE, Vol.110, No.2 @ASCE, ISSN 0733-9445/84/0002-0401, Paper no:18597.

4. Faisca, R.G. (2003), "Caracterizacao de cargas dynamics geradesporatividades humans (Characterization of Dynamic Loads due to Human activities)", "Ph.D Thesis (in Portuguese), COPPE/UFRJ, Rio de Janerio, RJ, Brazil, pp.1-240.

5. International standards of Organisation/ISO 2631-2: Evaluation of Human exposure to whole-body vibration. Part-2: Continuous and shock-induced vibration in buildings $(1-80 \mathrm{~Hz})$, "1989.

6. IS 800:2007, Indian Standard general construction in Steel code of practice- Third Revision.

7. Ivan M. Diaz and Paul Reynolds (2010), “Acceleration feedback control of human - induced floor vibrations", Journal of Engineering Structures, Vol.32, pp.163-173.

8. Kromanis.R. and Kripakaran.R. (2014), "Predicting thermal response of bridges using regression models derived from measurement histories", Journal of Computers and Structures, Vol.136, pp. 64-67.

9. Langer, N.A.dos S., Silva,J.G.S. daVellasco, P.C.G. da S, Lima,L.R.O and de, Neves, L.F. da C. (2009), "Vibration analysis of composite floors induced by human rhythmic activities", Proceedings of the 12th International Conference on Civil, Structural and Environmental Engineering Computing, CC, Funchal, IIha da Maderia, Portugal, CD-ROM, pp.1-14.

10. McGrath and Foote, D (1981), "What happened at the Hyatt? Newsweek National Affairs, United states edition, pp.26.

11. Nor Hayati and AbdGhafar (2015), "Dynamic Behaviour ofLVL Concrete Composite Flooring Systems".

12. Reiher, H. and Meister, F.J. (1931), "The effect of Vibration on People", published in German English Translation in Report No. F-TS-616-R.E.H.Q. Air Material Command, Wright Field, Ohio, 1949.

\section{AUTHORS PROFILE}

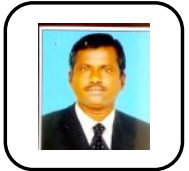

Mr. S. Karunanidhi, obtained his bachelors 'degree in Civil Engineering from PSNA College of Engineering \& Technology, Dindigul affiliated to Madurai Kamaraj university in 1998. He was awarded his masters degree in structural engineering from AC Tech, karaikudi affiliated to Anna university in 2009.He has published 5 international journals and also presented 4 papers in national and international conferences. Presently he is working as an Assistant professor in the department of civil Engineering, College of Engineering \& Technology, Wollega University, Ethiopia since 2013 with more than 19 years of teaching and industrial experience. He is a life time member of ISTE and Institute of Engineers (India).

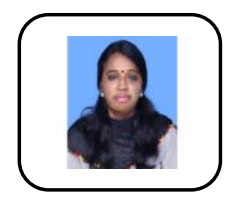

Dr.G.Gajalakshmi, completed her bachelor's degree in Civil Engineering from Periyar Maniammai college of Tech for women affiliated to Bharadidasan University in 1998. She obtained her degree M.E from Sathyabama University in 2008. She has been awarded her $\mathrm{PhD}$ degree in Civil Engineering/Structural Engg division from sathyabama University, Chennai, Tamilnadu, India in 2017.She has published 8 papers in international and national journals. Also she has published and presented 13 papers in national and international conferences. Now she is working as a lecturer in the department of civil Engineering, college of Engg \& Tech, Wollega University, Ethiopia with more than 17.5 years of teaching, research and industrial experience.

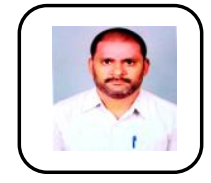

Mr. Y M S D Sastry, completed his bachelor's degree in Civil Engineering (Associate Member in Institute of Engineers) from Institute of Engineers India, Kolkata in 2003. He obtained his Masters degree M. Tech from Acharya Nagarjna University in 2010. He published good number of papers in international and national journals. Also he had published and presented good number of papers in national and international

conferences. Now he is working as Assistant Professor in the department of civil Engineering, Bonam Venkata Chalamayya Engineering College, Autonomous, Odalarevu, Allavaram Mandal, Affiliated to JNTUK, Kakinada, East Godavari District, Andhra Pradesh, with more than 18 years of teaching, research and industrial experience. He is a life time member of ISTE, CSI and Institute of Engineers (India).
Published By:

Blue Eyes Intelligence Engineering \& Sciences Publication (C) Copyright: All rights reserved.

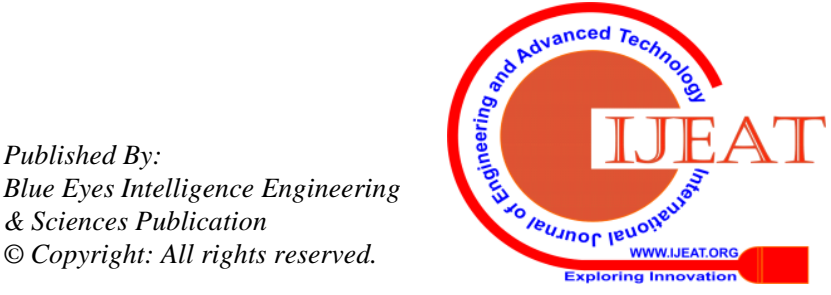

